\title{
What about the Vapostori now? The ambivalence of politics of relevance among indigenous churches in Zimbabwe
}

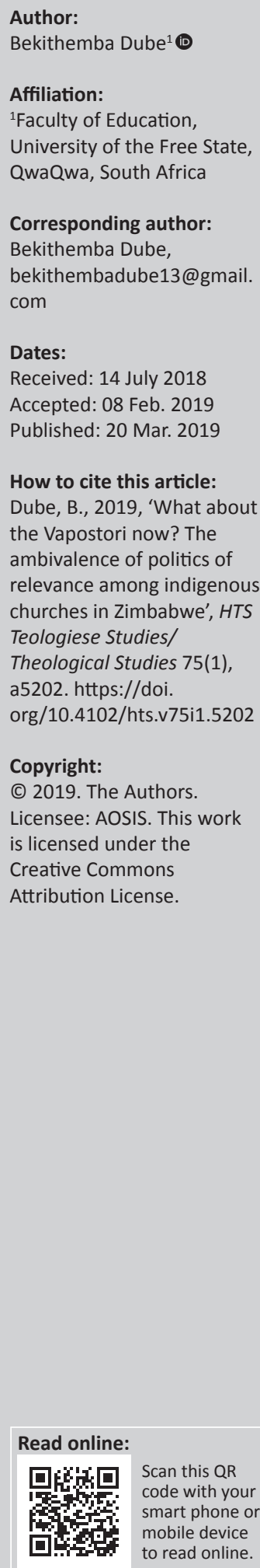

In this theoretical article, I problematise the role of Zimbabwe's Vapostori movement in the country's political and religious landscape. I contend that the Vapostori (white-garment churches) has, over the years, been active in attempting to ensure that the former president of Zimbabwe, Robert Mugabe, remained in power, while at the same time casting aspersions on political players of other persuasions and on other churches, and acting as a mobilisation tool of the political party, Zimbabwe African National Union Patriotic Front. In a quest for relevance, the Vapostori promoted the politics of hero worship. In problematising the role of the Vapostori in the political arena, I respond to two questions, namely, what themes or trajectories emanated from the nexus of the Vapostori and the Mugabe era; and how can an indigenous church achieve politics of relevance that are devoid of political capture and hero worship? To respond to these questions, I couch my views in critical emancipatory research, which advocates for social justice, emancipation and improvement of human conditions. The main argument of the article is that the Vapostori, in their quest to achieve a politics of relevance, should avoid centring their narratives around the idolisation of leaders, and hero worship, and instead, champion a theology that values social justice and religious collaboration.

'I Ndanga representing all Apostolic Sect members here and all those that are scattered around the country I handed over to him (Mugabe) the certificate that he will rule this country until he die,' he added. 'So go and tell Mugabe that he has that mandate till his death'. (New Zimbabwe 2017:1)

We have come here to show our support for President Mugabe. He can rule forever because he is the leader that was appointed by God. (Chimbalu 2013:3)

\section{Introduction}

In Zimbabwe's political conundrum, 21 November 2017 marked the start of a new era, with the end of Robert Mugabe's 37-year rule. To many people, myself included, this event came as a surprise because Mugabe's party, the Zimbabwe African National Union Patriotic Front (ZANU $\mathrm{PF}$ ), and many other parties had vowed that Mugabe would rule Zimbabwe until his death. African indigenous churches called the Vapostori spearheaded this idea, and buttressed Mugabe as the chosen leader of Zimbabwe. In fact, on 05 November 2017, at a Super Sunday rally organised by the Vapostori, Grace Mugabe addressed the Vapostori and thanked them for their support of ZANU PF and President Mugabe, and for their endorsement of him as a candidate for the presidential elections of 2018, which did not happen (he remained president), as prophesied and endorsed by the Vapostori.

Cognisant of the above, the role of the Vapostori during the Mugabe era is described by Brittain (2014:206) as ensuring 'ideological support of the nation-state, encouraging people to passively bear injustice in the hope of attaining reward in the afterlife'. This resulted in the creation of a church that disregards justice and the views of people with differing political opinions. Washington, Van Buren and Patterson (2014:181) claim that such behaviour is a force that threatens Africa's security, politics and development because church people cannot effectively contribute to the democratisation of society, appreciation of difference and championing of social justice - the hallmarks of progress.

This article is guided by the following two research questions: what themes or trajectories emanated from the nexus of the Vapostori and the Mugabe era? How can an indigenous church achieve a politics of relevance that is devoid of political capture and hero worship? In response to these questions, I highlight various emerging issues related to the nexus of Mugabe and the 
Vapostori; these issues are characterised by, among other phenomena, social injustice, hero worship and blasphemy. I also suggest ways in which the Vapostori can develop a practical theology that moves towards a politics of relevance, devoid of bootlicking and hero worship, and self-configured prophecies that negate social justice.

\section{Theoretical framework: Critical emancipatory research}

This article is couched in critical emancipatory research (CER), which has its 'philosophical roots in several traditions, such as Marx's analysis of socio-economic conditions and class structure, Haberman's notion of emancipatory knowledge and Freire's transformative and emancipatory pedagogy' (Nkoane 2013:99).

Curpas (2013:12) explains that CER emanated from the context of the struggle of the working class, as an instrument of the envisioned Marxian revolutionary knowledge and action associated with the need for justice in society. In fact, as suggested by Demirovic (2013:1), CER attempts to engage scholars in critical examination, and to challenge exploitative conditions in every sphere where these conditions may appear. In this case, exploitation is exhibited by the actions of the Vapostori in the Zimbabwean political landscape. CER works to achieve emancipation, which attempts to liberate the individual from bonds of identity (Demirovic 2013:10).

The theory of CER is relevant to the problematisation in this article because it provides 'societies with common languages by which to address people's hopes and discontents' (Mendieta 2005:80). In the context of the nexus of religion and politics in Zimbabwe, CER strives for 'the possibilities of democratic politics and toward the simultaneously theoretical and emancipatory task of revealing the distortions of contemporary politics' (Anderson 2011:35). It challenges and emancipates politicians and religious leaders to use religion in forms that support social justice, social transformation and equal democratic participation of all citizens. To achieve this goal, CER 'looks at, exposes, and questions hegemony, traditional power assumptions held about relationships, groups, communities, societies, and organisations to promote social change' (Given 2008:140), which is the thrust of this article.

\section{The Vapostori movement in Zimbabwe}

The Vapostori forms part of the African Instituted Churches, a group of independent Christian churches with their roots in the African continent; hence, on some platforms, they are referred to as indigenous churches. The Vapostori are:

\footnotetext{
congregations and or denominations ... planted, led, administered, supported, propagated, motivated [and] funded by Africans for the purpose of proclaiming the Gospel of Jesus Christ and worshipping the Triune God in the context and world-view of Africa and Africans. (Oduro 2004, quoted by Oduro 2010)
}

In the case of Zimbabwe, the Vapostori is also referred to as the Masowe people or Mapostori (Mapuranga 2013:online). In this article, the Vapostori indigenous churches include the Zion Christian Church (ZCC), Johane Marange, Johane Masowe we Chishanu, African Apostolic Church, Independent African Church and GutaRaJehova (Mapuranga 2013:online), though this list is not exhaustive. The major identifiers of these churches are that members wear white garments and worship in the open, usually under trees. Men are identified by bald heads and long beards.

\section{Trajectories of Vapostori movements in the political landscape}

In this section, I highlight various trajectories or emerging themes that arose from the nexus of the Vapostori church and politics in Zimbabwe. In an attempt to create a democratic milieu in Zimbabwe, these trajectories should, in the future, be treated with wariness by Zimbabweans. Although religion is becoming more important in African life, when it is not problematised with a lens of CER, it creates new challenges for society (Abbink 2014:94), as will be explained in the subsequent sections.

\section{Religion as tool of political mobilisation}

The role played by religion in post-colonial sub-Saharan Africa has been contentious, especially in light of pertinent concerns, such as political stability, dictatorship, human rights, democracy, civil society, social justice, economic development, corruption and health (Hansen \& Twaddle 1995:1). In relation to the Vapostori in Zimbabwe, in addition to fulfilling various faith mandates, the Vapostori has assumed the role of political mobiliser of votes in favour of ZANU PF. Generally, some Vapostori members target for political mobilisation, as a result of perceived spiritual or divine forces recognised by politicians (Abbink 2014:92), and the large following the Vapostori commands. This leads politicians to view the Vapostori as rich hunting grounds for enlarging political power. Interestingly, the post-Mugabe Vice-President of Zimbabwe, General Chiwenga, just before his appointment to office, visited the Vapostori shrine. In some quarters his action could be interpreted as an act of political mobilisation and legitimisation of the perceived coup (Nkosi 2017).

In shedding light on why the Vapostori and other religious movements succumb to politicisation, Aguwa (1993) explains that religion inclines towards dialogic relationships with several other sociocultural institutions for personal gain; thus, politicians understand that survival of people is centred around religion, and when politicians capture religion, it becomes easy to manipulate people. To illustrate the extent of political capture of religion to facilitate mobilisation and ideological infusion, I refer to the case of an all-night prayer at Juranifiri Santa Shrine, during which the Vapostori sang ZANU PF liberation war songs, instead of Christian hymns, and held up ZANU PF placards (Engelke 2007:249). 
Confirming this report, ZimEye (2017) notes that ZANU PF has always used the church as its favourite hunting ground, with Mugabe and his top officials leading the campaign to remain in power.

It became a tradition in ZANU PF that, before every general election, Mugabe would visit the Vapostori, especially the John Marange Church in Manicaland (Ndlovu 2011). Ndanga, the leader of the Vapostori, is quoted by ZimDaily (2013) as saying, 'Just wait and see. We want to show our power by swinging the votes in favour of Zanu $\mathrm{PF}^{\prime}$, thereby indicating that the movement was mobilising for ZANU PF. In turn, politicians sang the praises of the contribution of the Vapostori regarding political mobilisation. Mushanawani (2014) quotes former President Mugabe's appreciation of the church's contribution:

You are a true church who lead by example and 'walk your talk'. You declared here and prophesied the resounding victory of Zanu-PF over MDC factions in the 31st July 2013 harmonised elections, a few weeks earlier. You advised me to go and have peaceful sleep. 'Yes, your prophecy came out undiluted and as predicted. Thanks for your resolute support to Zanu-PF'. (p. 1)

In reciprocal appreciation, some members of the Johane Marange Apostolic Church, Johane Masowe we Chishanu Apostolic Church and African Apostolic Church were coopted by ZANU PF to the political ideology of authoritarian nationalism; this made the Vapostori an indispensable constituency for victory in national elections (Machoko 2013:1). Samukange, Laiton and Matenga (2014) note that ZANU PF youths are seen as the vanguard of the party, and they are fully behind the Vapostori. Furthermore, Ndanga, the Vapostori leader, is cited by Zim Mail (2014) as saying, 'we would want to sign a pact with ZANU PF which should see us land the post of the vice president'. Consequently, ZANU PF's control of state apparatus and politics was entrenched, to the extent that even the most liberal Vapostori leaders ended up captives of ZANU PF's political ideology, and served its needs and aspirations, including mobilising church members for political gain. One may argue that the Vapostori has been captured by the state; thus, balancing a religious mandate and a political mandate has become a contested terrain, in which Vapostori's relevance becomes questionable.

I concede the right of individuals in the Vapostori movement to exercise their political and constitutional rights to belong to a party; however, through the lens of CER, it is wrong to force all church members to be part of and to support a political agenda at the expense of individual choice and moral obligation. Not all Vapostori are members of either ZANU PF or the Movement for Democratic Change; thus, the assumption by Vapostori leaders that all people belong to political parties that offer political benefits does not reflect social justice and the right to make moral decisions. For example, in 2011, a ZANU PF politician, Webster Shamu, attempted to address Vapostori at their annual general meeting, which is popularly known as musangano wegore. Despite having received blessings from the so-called
Vapostori leaders, he was roundly booed, and many church members walked away, leaving him talking to grass, trees, lizards and, of course, a few humans (Chimbalu 2014). In support, Conger (2011) reports, African Instituted Churches - especially the ZCC and the Vapostori - are being pressed into service by the regime to cement its hold on power. In this regard, I agree with Machoko (2013:1) that co-optation of the Vapostori into ZANU PF's political ideology was achieved through the combined use of violence and bribery of church members and leaders. My argument is that when the religious elite connive with politicians to achieve political mobilisation, and pretend that their views represent and satisfy the whole populace of the Vapostori, it is tantamount to social injustice being perpetrated, which the Vapostori should resist in a quest to regain political and religious relevance in Zimbabwe.

\section{Dismantling dissenting voices}

The Vapostori movement not only consolidated the power of Mugabe and ZANU PF, but went further to castigate elements that held political views that differed from that of the Vapostori. The attempt was, arguably, to silence dissenting voices and to create a dichotomy between the white-garment churches and missionary churches. The situation was exacerbated by the belief of Mugabe and ZANU PF that mission churches were elements promoting regime change, sponsored by the West. Because of the dichotomy created within the Christian church through the nexus of the Vapostori and ZANU PF, I disagree with the observation by Abbink (2014:89): religious leaders are not only community leaders and preachers, but also moral authorities who play mediating roles in solving local conflicts - also between people of different faiths or denominations, and they should not be promoting violence and hatred of people of difference. Thus, promoting violent tendencies by quashing dissenting voices must be resisted as far as possible (Rasool 2004:97). In this regard, I agree with the observation by Ndlovu-Gatsheni (2013):

What African people must be vigilant against is the trap of ending up normalising and universalising violence as a natural state of the world, however, it must be unmasked, resisted and destroyed because it produces a world order that can only be sustained through a combination of violence, deceit, hypocrisy and lies. (p. 10)

To develop the dismantling of dissenting voices, theme or trajectory, Ndanga, addressing the Vapostori in Magunje, reprimanded war veterans for severing their ties with Mugabe; he described doing so as an act of indiscipline (Saunyama 2016). As evidence of the attempt to quash voices of difference, Saunyama (2016:online) quotes Ndanga, who said that the Vapostori are:

\footnotetext{
... against the churches that emerge during times of crisis, and such churches should not be taken seriously. They have headquarters in the Western countries. The government should only work with the traditional churches like apostolic sects and all will be fine. (p. 1)
}

In this light, Tutani (2017:online) is right to point out that 'invariably these vapostori leaders have been religious 
enablers of repression. They give spurious theological justification to tyranny saying President Robert Mugabe is God-ordained'. Again, Ndanga attacked Evan Mawarire, the leader of this flag movement, and described Mawarire as self-ordained (Zambezi Post 2017) and a 'religious charlatan masquerading as a man of God yet he is a devil's advocate'. In another attempt to quash emerging voices, the Vapostori castigated Prophet Makandiwa of the United Family Interdenominational Church and Prophet Magaya of Prophetic, Healing and Deliverance Ministries, for resisting the bond notes (the current currency used in Zimbabwe), and described the prophets as anti-government (Dewa 2016).

Through the lens of CER, the art of dismantling voices of difference is tantamount to social injustice, and represents oppression, which must be resisted. To the same extent that the Vapostori have the right to exist and to practice religion within the confines of the constitution, mission churches or different-minded religious movements have the right to make representations within political narratives, as harbingers of existing ideology, or otherwise. If the narratives of the Vapostori are centred around supporting and consolidating a repressive system, then religion is losing its relevance in democratic society. Washington et al. (2014:186) are right to point out that religious institutions and leaders have been crucial to democratic transitions in Africa; however, Vapostori leaders can be described as an 'impediment to economic advancement, and irrelevant for modern societies' (Lunn 2009:939); hence, through the lens of CER, their influence must be challenged.

\section{Heretical teachings}

By heretical teachings, I mean teaching that does not correlate with the teaching of Jesus as depicted in the Bible. To remain relevant in the political space and narratives, the Vapostori sang the praises of Mugabe and ZANU PF. In a quest for political relevance through hero worship, the Vapostori went as far as promoting heretical teachings. My argument is cognisant of the tendency that, as far as politics goes, religious interpretations do not always lead us to the same side of the political fence (Sontag 1989:4).

To gain relevance to and favour with Mugabe and ZANU PF, Vapostori described Mugabe as supreme and carrying the blood of Jesus: so we cannot throw him away. He is the chosen one (Ndou 2011). At Morris Depot, Mugabe was likened to Jesus Christ (Zimbabwe Independent 2016). Speaking at an interface rally, former ZANU PF leader, Chipanga, cited by Jena (2017), mooted that:

He is our Messiah, just like Jesus Christ when he liberated the world. Jesus, when he came, liberated the world and when President Mugabe came, he liberated us in this age ... we honour God, then Jesus Christ and President Mugabe. (p. 1)

In addition, during the Mugabe era, Nehemiah Mutendi, a leader of the Vapostori, described Mugabe as greater than the prophets of the Bible (Religion in Zimbabwe 2016). In turn, the Zimbabwe Council of Churches, with a different political and religious ideology, stated that Mugabe must resist using blasphemous names, and argued that this kind of blasphemous idolatry is not only dangerous to the nation, but also kills the receiver (Bulawayo24 2017).

The statements, reported above, show how religious figures encourage hero worship to achieve a politics of relevance and, in the process, create individuals who become so powerful that their delivery of social justice is not questioned. I argue that the creation of an oppressive regime in Zimbabwe was accomplished by people who, in the quest for political relevance, believed that hero worship was the only way to achieve success. It can be concluded that countries in Africa, in the post-colonial era, have to deal with identity crisis determined by an individual who exploits the people who hero-worship him or her.

In this section, I used the CER lens to show how the Vapostori, in a quest for political relevance, 'dominated, alienated and marginalised certain individuals and groups' (Abel \& Sementelli 2002:253). In the following section, I propose a way for the contested terrain to be reconstructed for relevance. I suggest ways in which the Vapostori and other religious leaders can find relevance devoid of hero worship, oppression and social injustice, for the betterment of both a religious and a political mandate.

\section{Reconstructing Vapostori faith to achieve relevance in the political conundrum}

The relevance of the Vapostori in the political conundrum in Zimbabwe cannot be maintained on the basis of hero worship and bootlicking politics. Therefore, a reconstruction of practical theology is necessitated by the need for a religion that is free of manipulation and dehumanisation that creates a false sense of reciprocal support. Thus, in this section, I suggest ways in which the Vapostori can find relevance in the new political dispensation going forward, with either ZANU PF or any other political players occupying the political space. Politics of relevance could serve not only the Vapostori, but society too, in a quest for democracy. I am convinced that the Vapostori have a very important role in society, and this article does not seek or intend to undermine this role, but to enhance it, by suggesting the following approach to achieve political relevance, instead of political capture.

\section{A social justice-oriented political system}

The Vapostori has a constitutional right to be involved in Zimbabwe's political landscape; however, I disagree with the politics of hero worship. Rather, to achieve political and social relevance, there is a need to exorcise the hero worship mentality, by developing a social justice-oriented system that does not find its relevance in individuals who come and go, but in systems. The Vapostori need to develop a political relational system that is underpinned by social justice, which involves recognising and positively valorising cultural diversity, as suggested by Fraser (1996:7). 
Social justice is achieved by addressing the way economic, political and social benefits and burdens are distributed in society (Chipkin \& Gibert 2013:7); it implies liberal equality that upholds equal rights to freedom of speech, freedom of religion, democratic citizenship and so on for every member of society (Arneson 2007:4) - 'social justice involves working together to establish a just society' (Brady 2010:8).

Furthermore, it refers to a situation in which there is economic justice, public participation and social cohesion centred on fulfilling a moral obligation to do good for the community (Chipkin \& Gibert 2013:7).

Current credence systems, as articulated by Vapostori leaders, are treated as truths by the dominant class and act as barriers to conscious exercise of freedom (Lindsey, Sheilds \& Stajduhar 1999:1241). Championing social justice in the political arena, Kreber (2005:397) argues, will enable adherents to 'gain insight through critical reflection to effect change or improve the political participation'. Under this pretext, the Vapostori can 'practice religion and politics free of superstition and prejudice' (Steinvorth 2008:400) because there will be an 'awakening of consciousness and awareness of social injustices, motivating self-empowerment and social transformation' (Stinson 2009:506).

I am aware that this suggestion might be demanding, and could create more enemies than friends among politicians for the Vapostori, yet it is desirable, possible and achievable in the quest for relevance. For the Vapostori, championing social justice is a dream delayed, one that the nexus of ZANU $\mathrm{PF}$ and the Vapostori has denied the church. I argue that it is still possible for the Vapostori to occupy a central point in transforming society through social justice.

\section{Strive for collaboration with religious others}

Mugabe was successful in creating a dichotomy between the Vapostori, on the one hand, and other religious movements or churches in Zimbabwe, on the other. As a result, the prophetic voice of the church has been compromised and made irrelevant in relation to the lived realities of the people of Zimbabwe. If the Vapostori and the church are to remain relevant in the political arena, there is a need for unity.

Proposing unity does not mean that I do not appreciate diversity; on the contrary, a multiplicity of prophetic narratives is essential. However, they should coexist in a spirit of respect and emancipation, and with the goal of improving the human condition. Achieving this spirit could prevent the colonisation or political capture of the church, and 'mechanization of the lifeworld by power and money and develop a society based on free and undistorted communication' (Habermas 1987:183). Collaboration, Dube (2016:27) contends, will allow churches to become a public domain for all, in many ways, and will reduce the prejudice, misinterpretation and misrepresentation of religious ideologies that may fuel conflict in society.

\section{Value of the article}

The value of this article is that it contends and problematises the role of the Vapostori in the political arena. It does so by providing evidence of the various ways in which some Vapostori movements derail social justice and the emancipation of the people. By problematising the role of the Vapostori, I entered into the struggle described by Alvesson (1992), through which:

... individuals and groups become freed from suppressive social and ideological situations, particularly those that place socially unnecessary precincts upon development and enunciation of human consciousness and consequently people acquire an exercise power over their thought processes, life-worlds to change oppressive conditions. (p. 432)

The article challenges religious players, especially leaders, to realise that their alliances and the possibility of political capture cause suffering for the masses. The article is of value because it proposes a reconstruction of practical theology, of which the thrust is a theology that is devoid of social injustice and hero worship of individuals.

\section{Limitation of the article}

This article's focus is limited to the Vapostori, even though other church leaders, such as Kunonga of the Methodists, are also pro-ZANU PF. Although it may be true that some other churches also played a role in sustaining Mugabe's power, the article focuses only on the Vapostori. The article assumes that all Vapostori are agents of ZANU PF, which is, of course, not representative of the views of all the Vapostori in Zimbabwe.

I acknowledge that the Vapostori also make positive contributions to the community in Zimbabwe; however, these contributions were not the scope of this article. At this point I invite other scholars, who study religion and social justice, to either problematise the article or enhance its argument, with the ultimate goal of enhancing the role of the church in the political space and to respond to human needs.

\section{Conclusion}

In this article, I highlighted and problematised various themes or trajectories that emerged from the nexus of the Vapostori and ZANU PF in Zimbabwe's political arena. I argued that the politics of relevance for the Vapostori church does not emanate from hero worship, but should be based on reciprocal relations, informed by the creation of a system underpinned by principles such as social justice, accountability and emancipation. I based my arguments on CER, of which the agenda is to challenge all forms of social injustice. I also pointed out how relevance devoid of political capture could be achieved. The value and limitation of the article were also explained. 


\section{Acknowledgements Competing interests}

The author declares that he has no financial or personal relationship(s) that may have inappropriately influenced him in writing this article.

\section{References}

Abbink, J., 2014, 'Religion and politics in Africa: The future of "the secular"', Africa Spectrum 49(3), 83-106. https://doi.org/10.1177/000203971404900304

Abel, C.F. \& Sementelli, A., 2002, 'Power, emancipation and administrative state', Administrative Theory and Praxis 24(2), 253-278. https://doi.org/10.1080/10841 8dministrative Theory

Aguwa, J.C.U., 1993, Religious dichotomy in Nigerian politics, Fourth Dimension Publishing Company, Enugu.

Alvesson, M., 1992, 'On the idea of emancipation, management and organization studies', Academic of Management Review 17(3), 432-454. https://do org/10.5465/amr.1992.4281977

Anderson, J., 2011, 'Situating Axel Honneth in the Frankfurt school tradition', in D. Petherbridge (ed.), Axel Honneth: Critical essays, with a reply by Axel Honneth, pp. 31-57, Brill, Leiden.

Arneson, R.J., 2007, 'Does social justice matter. Brian Barry's applied political philosophy. Symposium on Brian Barry's "Why social justice matters"', Ethics 117 391-412. https://doi.org/10.1086/511732

Brady, J.A.O.P., 2010, 'A burning desire for social justice', Religious Education 105(1), 8-11. https://doi.org/10.1080/00344080903472634

Brittain, C.C., 2014, 'The Frankfurt school of religion', Religion Compress 6(3), 204212. https://doi.org/10.1111/j.1749-8171.2012.00339

Bulawayo24, 2017, 'Mugabe warns of God's wrath', Bulawayo24 News, 21 September, viewed n.d., from https://bulawayo24.com/index-id-news-sc-national-byo-118222

Chimbalu, M., 2013, 'Vapostori graces opening of parliament', ZimNews, 21 September, viewed n.d., from www.zim.org/news/vapostori-graces-openingparliament

Chimbalu, N., 2014, 'Why ZANU PF is afraid of Johanne Masowe', Nehanda Radio, 13 August, viewed n.d., from www.nehandaradio.com/why/zanupf/is/afraid/of/ johanne/masowe

Chipkin, I. \& Gibert, S.M., 2013, Understanding the social justice sector in South Africa A Report to the RAITH Foundation and Atlantic Philanthropies, The Raith Foundation, Houghton, South Africa.

Conger, G., 2011, 'Zimbabwe churches told to support ruling party - Or else', Christianity Today News \& Reporting, 10 August, viewed n.d., from www.youtube. $\mathrm{com} /$ watch? $=$ = gJ67j7KPcDo

Curpas, A., 2013, 'Aesthetic reasoning. The rehabilitation of the non-identical', Annales Philosophici 2013(7), 11-24.

Demirovic, A., 2013, Foucault, Gramsci and critical theory: Remarks on their relationships, viewed n.d., from http://internationalpsychoanalysis-net.ipbooks. net/2013/06/25/foucault-gramsci-and-critical-theory-remarks-on-theirnet/2013/06/25/foucault-gr
relationship-by-alex-demirovic/

Dewa, T., 2016, 'Archbishop Ndanga backs bond notes, attacks Makandiwa and Magaya', Nehanda Radio, 17 August, viewed n.d., from http://nehandaradio. com/2016/08/17/archbishop-ndanga-backs-bond-notes-attacks-makandiwamagaya/

Dube, B., 2016, 'A socio-religious hybridity strategy to respond to the problems of religious studies in Zimbabwe', PhD thesis submitted to the University of the Free State, Bloemfontein, South Africa.

Engelke, M.E., 2007, A problem of presence: Beyond scripture in an African church, University of California Press, Berkeley, CA.

Fraser, N., 1996, Social justice in the age of identity politics: Redistribution, recognition and participation, The Tanner Lectures on Human Values, Stanford University, Stanford, CA

Given, L.M. (ed.), 2008, The Sage encyclopaedia of quantitative research methods, Sage, London.

Habermas, J., 1987, 'Further reflections on the public sphere', in C. Calhoun (ed.) Habermas and the public sphere, pp. 421-461, MIT Press, Cambridge, MA.

Hansen, H.B. \& Twaddle, M., 1995, Religion and politics in east Africa: The period since independence, James Curry, London.

Jena, N., 2017, 'Mugabe equal to Jesus Christ: Chipanga', NewsDay Zimbabwe, 05 July, viewed n.d., from https://www.newsday.co.zw/2017/07/mugabe-equal-jesuschipanga/

Kreber, C., 2005, 'Charting a critical course on the scholarship of university teaching', Studies in Higher Education 30(4), 389-405. https://doi.org/10.1080/03075070 500160095
Lindsey, E., Sheilds, L. \& Stajduhar, K., 1999, 'Creating effective nursing partnerships: Relating community development to participatory action research', Journal of Advanced Nursing 29(5), 1238-1245. https://doi.org/10.1046/j.1365-2648. Advanced Nursi

Lunn, J., 2009, 'The role of religion, spirituality and faith in devil: A critical theory approach', Third World Quarterly 30(5), 937-951. https://doi.org/10.1080/ 01436590902959180

Machoko, C.G., 2013, 'African initiated churches and party politics: Zimbabwean experience', The International Journal of African Catholicism 4(1), 1-40.

Mendieta, E. (ed.). 2005. The Frankfurt school on religion. Key writing by the major thinkers, Routledge, New York.

Mapuranga, T.P., 2013, 'AICs as a gendered space in Harare, Zimbabwe: Revisiting the role and place of women', Studia Historiae Ecclesiaticae 39(2), viewed n.d., from http:// www.scielo.org.za/scielo.php?script=sci_arttext\&pid=S1017-04992013000200017

Mushanawani, C., 2014, 'President salutes Vapostori', Nehanda Radio, 19 July, viewed n.d., from www.nehandoradio.com/2014/07/19/president-salutes-vapostori/

Ndlovu, R., 2011, 'Mugabe push for pulpits pulling power', Mail \& Guardian, 16 September, www.//mg.co.za/article/2011-09-16-mugabe-push -for-pullpit

Ndlovu-Gatsheni, S.J., 2013, 'Why decoloniality in the 21st century?', The Thinker for Thought Leaders 48(February), 10-16.

Ndou, P., 2011, 'Zanu PF. Infiltration of Vapostori exposed, Vapostori chants pamberi ne Zanu PF', Bulawayo24, 15 June, viewed n.d., from https://bulawayo24.com/ index-id-news-sc-national-byo-4650-article-zanu-pf+infiltration+of+vapostori+ex posed,+vapostori+chants+pamberi+ne+zanu-pf.html

New Zimbabwe, 2017, 'Zimbabwe: Vapostori leader says Mugabe certified to rule till death, free housing stands for his followers to guarantee Zanu-PF 2018 victory', NewZimbabwe.com, 07 November, viewed n.d., from http://allafrica.com/stories/ 201711070213.html

Nkoane, M.M., 2013, 'Creating sustainable postgraduate supervision learning environment through critical emancipatory research', TD the Journal of Transdisciplinary Research in Southern Africa 9(3), 393-400. https://doi.org/ 10.4102/td.v9i3.186

Nkosi, R., 2017, 'Chiwenga visits Vapostori shrine', ZimEye Media, 23 December, viewed n.d., from https://www.zimeye.net/2017/12/23/picture-blast-chiwengavisits-vapostori-shrine/

Oduro, T., 2010, 'Contributions and challenges of the African Instituted Churches in developing African theology', in D.B. Stinton (ed.), African theology on the way. Current conversations, Society for Promoting Christian Knowledge, London.

Rasool, E., 2004, 'Religion and politics in South Africa', in D. Chidester, A. Tayob \& W. Weisse (eds.), Religion, politics, and identity in a changing South Africa, Volume 6: Religion and society in transition, pp. 97-102, Wazmann, Münster.

Religion in Zimbabwe, 2016, 'People must desist from blasphemous remarks', Religion in Zimbabwe, 29 March, viewed n.d., from https://relzim.org/forum/religion-andsociety-blog/people-must-desist-from-blasphemous-remarks/

Samukange, T., Laiton, C. \& Matenga, M., 2014, 'Zanu PF youths burn Vapostor shrine', NewsDay Zimbabwe, 03 June, viewed n.d., from www.newsday.com/ zanupf/burn/vapostori/shrine

Saunyama, J., 2016, 'War veterans should apologise: Vapostori', NewsDay Zimbabwe, 08 August, viewed n.d., from www.zimbabwesituation.com/war/veterans/ should/apologise/vapostori

Sontag, S., 1989, AIDS and its metaphors, Farrar, Strauss \& Giroux, New York.

Steinvorth, U., 2008, 'On critical theory', Analyse and Kritik 30, 399-423. https://doi. org/10.1515/auk-2008-0204

Stinson, D.W., 2009, 'The proliferation of theoretical paradigms quandary. How one novice researcher used eclecticism as a solution?', The Qualitative Researcher 14(3), 498-523.

Tutani, C., 2017, 'Christians should not follow blindly like sheep', NewsDay Zimbabwe, 27 October, viewed n.d., from www.newsday.co.zw/christians/should/not/ follow/blindly/like/sheep

Washington, M., Van Buren, H.J. \& Patterson, K.D.W., 2014, 'Pastor practices in the era megachurches: New organisational practices and forms for a changing institutional environment', in P. Tracey, N. Phillips \& M. Lounsbury (eds.), Religion and organization theory. Research in the sociology of organizations, vol. 41, pp. 187213, Emerald Group Publishing, Bradford.

Zambezi Post, 2017, 'Grace Mugabe breaks into Vapostori sect', Zambezi Post, 25 October, viewed n.d., from www.grace/mugabe/breaks/into/the/Vapostori

Zimbabwe Independent, 2016, "Mugabe is like Jesus Christ": What blasphemous drivel!', Zimbabwe Independent, 05 August, viewed n.d., from https://www. theindependent.co.zw/2016/08/05/mugabe-like-jesus-christ-blasphemoustheind
drivel/

ZimDaily, 2013, 'Vapostori vow to vote for Mugabe', ZimDaily, 24 February, viewed n.d., from www.zimdaily.com/vapostori/vow/to/vote/for/mugabe

ZimEye, 2017, 'Controversial Ndanga, attackers Mawarire, says he is a fake prophet', ZimEye, 17 August, viewed n.d., from https://www.zimeye.net/2016/08/17/ controversial-ndanga-attacks-mawarire-says-hes-a-fake-pastor-2/

Zim Mail, 2012, Vapostori leader fingered in Zanu PF succession, viewed 04 August 2014, from https://bulawayo24.com/index-id-news-sc-national-byo-51666article-vapostori+leader+fingered+in+zanu+pf+succession.html 